\title{
A population model of the thalamo-cortical system during deep sleep
}

\author{
Michael Schellenberger Costa ${ }^{1 *}$, Arne Weigenand ${ }^{1,2}$, Thomas Martinetz ${ }^{1}$, Jens Christian Claussen ${ }^{1,2}$ \\ From Twenty Second Annual Computational Neuroscience Meeting: CNS*2013 \\ Paris, France. 13-18 July 2013
}

Sleep has been shown to be crucial for the consolidation of memories, which can be enhanced by sensory or electric stimulation during slow wave sleep $[1,2]$. As the thalamo-cortical interaction is important for both the processing of sensory stimuli and the generation of slow waves a detailed understanding of its dynamical properties is needed, to reveal the influence of one on the other. Population models have been used to investigate the behaviour of brain networks, may it be within specific regions [3] or between different structures of the brain [4]. Although they are able to reproduce a vast variety of oscillatory behavior of the awake brain [5], these models lack the hallmarks of a sleeping thalamus e.g. rebound bursts and waxing/waning of spindles. This is due to the fact that these models solely focus on the synaptic interaction between neural populations, while neglecting their intrinsic properties. However specific currents in the thalamic relay and reticular neurons are necessary for the generation of spindle activity and rebound bursts [6]. Therefore we adapt a cortical population model proposed by [7] to reflect the connectivity found within thalamic nuclei and extend it with the respective Hodgkin-Huxley type currents. We adjust the thalamic model to show the right oscillatory behaviour and investigate the interaction with the cortical region.

\footnotetext{
Author details

${ }^{1}$ University of Lübeck, Institute for Neuro- and Bioinformatics, Germany. ${ }^{2}$ University of Lübeck, Graduate School for Computing in Medicine and Life Science, Germany.
}

Published: 8 July 2013

\section{References}

1. Marshall $L$, Helgadóttir $H$, Mölle $M$, Borns J: Boosting slow oscillations during sleep potentiates memory. Nature 2006, 444(7119):610-3, November.

2. Ngo HW, Martinetz T, Born J, Mölle M: Rhythm matters Closed-loop nudging of sleep slow oscillations to enhance memory. Neuron 2013, accepted.

3. Ursino M, Cona F, Zavaglia M: The generation of rhythms within a cortical region: analysis of a neural mass model. Neurolmage 2010, 52(3):1080-94, september.

4. Sotero RC, Trujillo-Barreto NJ, Iturria-Medina Y, Carbonell F, Jimenez JC: Realistically coupled neural mass models can generate EEG rhythms. Neural computation 2007, 19(2):478-512, February.

5. Bhattacharya BS, Coyle D, Maguire LP: A thalamo-cortico-thalamic neural mass model to study alpha rhythms in Alzheimer's disease. Neural networks 2011, 24(6):631-45, August.

6. Destexhe A, Sejnowski TJ: Interactions between membrane conductances underlying thalamocortical slow-wave oscillations. Physiological reviews 2003, 83(4):1401-53, October.

7. Steyn-Ross D, Steyn-Ross M, Sleigh JW, Wilson M, Gillies IP, Wright J: The Sleep Cycle Modelled as a Cortical Phase Transition. Journal of Biological Physics 2005, 31(3-4):547-569, December.

doi:10.1186/1471-2202-14-S1-P68

Cite this article as: Costa et al:: A population model of the thalamocortical system during deep sleep. BMC Neuroscience 2013 14(Suppl 1): P68.

* Correspondence: schellenberger@inb.uni-luebeck.de

${ }^{1}$ University of Lübeck, Institute for Neuro- and Bioinformatics, Germany

Full list of author information is available at the end of the article

Submit your next manuscript to BioMed Central and take full advantage of:

- Convenient online submission

- Thorough peer review

- No space constraints or color figure charges

- Immediate publication on acceptance

- Inclusion in PubMed, CAS, Scopus and Google Scholar

- Research which is freely available for redistribution

Submit your manuscript at www.biomedcentral.com/submit
C Biomed Central

\section{Biomed Central}

